Research Article

\title{
Development and Validation of an HPLC Method for Determination of Antidiabetic Drug Alogliptin Benzoate in Bulk and Tablets
}

\author{
Hani Naseef $\mathbb{D}^{1,2}$ Ramzi Moqadi ${ }^{1}{ }^{2}$, and Moammal Qurt $\mathbb{i D}^{2}$ \\ ${ }^{1}$ Samih Darwazah Institute for Pharmaceutical Industries, Faculty of Pharmacy, Nursing and Health Professions, \\ Birzeit University, Birzeit, State of Palestine \\ ${ }^{2}$ Pharmacy Department, Faculty of Pharmacy, Nursing and Health Professions, Birzeit University, Birzeit, \\ State of Palestine \\ Correspondence should be addressed to Moammal Qurt; mqurt@birzeit.edu
}

Received 25 July 2018; Accepted 3 September 2018; Published 24 September 2018

Academic Editor: Josep Esteve-Romero

Copyright (C) 2018 Hani Naseef et al. This is an open access article distributed under the Creative Commons Attribution License, which permits unrestricted use, distribution, and reproduction in any medium, provided the original work is properly cited.

\begin{abstract}
Alogliptin benzoate, a member of dipeptidyl peptidase- 4 inhibitors, is a recent drug developed by Takeda Pharmaceutical Company for the treatment of Type 2 diabetes; it potentiates the effect of incretin hormones through the inhibition of their degradation. Alogliptin can be used alone or in combination therapy. A new sensitive and rapid HPLC method was developed for the determination of alogliptin benzoate in bulk and pharmaceutical dosage forms; it was validated according to ICH and FDA guidelines. The HPLC analysis was performed on the Agilent 1200 system equipped with a Hypersil Gold Thermo Scientific C18 $(250 \mathrm{~cm} \times 4.6 \mathrm{~mm}) 5 \mu \mathrm{m}$ column, with a mixture of acetonitrile and ammonium carbonate buffer in the ratio of $55: 45 \mathrm{v} / \mathrm{v}$ as the mobile phase, at the flow rate of $1.0 \mathrm{~mL} / \mathrm{min}$. The detection was performed at the wavelength $(\lambda)$ of 277 , and the retention time of alogliptin benzoate was around $4 \mathrm{~min}$. The total run time was $6.0 \mathrm{~min}$. The calibration plot gave linear relationship over the concentration range of $85-306 \mu \mathrm{g} / \mathrm{ml}$. The LOD and LOQ were 0.03 and $0.09 \mu \mathrm{g}$, respectively. The accuracy of the proposed method was determined by recovery studies and was found to be $100.3 \%$. The repeatability testing for both standard and sample solutions showed that the method is precise within the acceptable limits. RSD\% of the determination of precision was $<2 \%$. The results of robustness and solutions stability studies were within the acceptable limits as well. The proposed method showed excellent linearity, accuracy, precision, specificity, robustness, LOD, LOQ, and system suitability results within the acceptance criteria. In addition, the main features of the developed method are low run time and retention time around 4 min.
\end{abstract}

\section{Introduction}

Since the first evidence about a known case of diabetes mellitus nearly 3000 years ago and despite the great deal of research that has been done recently, diabetes mellitus is still a wide spread serious disease that affect the life quality of millions of people worldwide. It is estimated that the number of patients with diabetes mellitus will rise to about 592 millions by the year $2035[1,2]$.

It was until the year 1936 that diabetes mellitus was distinguished to Type 1 and Type 2 [1]. Two main features of Type 2 diabetes mellitus is the increased cell resistance to insulin and the dysfunction of the insulin-producing cell in the pancreas ( $\beta$-cells) $[2,3]$. The first line of therapy for the treatment of Type 2 diabetes is metformin, but as the disease progresses, a drug combination may be a must [4].

Incretin hormones are secreted in response to eating food from the gastrointestinal tract to the blood stream and can stimulate insulin secretion and help control glucose levels; that is, they prepare the body against increase in blood glucose. These hormones include glucagon-like peptide-1 and glucose-dependent insulin tropic polypeptide $[5,6]$. Dipeptidyl peptidase- 4 is an enzyme found in the human body that helps inactivate the incretin hormones, thus terminating their hypoglycemic effect [2]. Alogliptin a member of dipeptidyl peptidase- 4 inhibitors is a recent 
drug developed in 2010 by Takeda Pharmaceutical Company [2,7], which is used for the treatment of Type 2 diabetes, and it potentiates the effect of incretin hormones through inhibition of their degradation by the dipeptidyl peptidase-4 enzyme $[2,4]$. Alogliptin can be used alone or in combination therapy, and it is now approved in the USA and Europe also [5]. Alogliptin is 2(\{6-[(3R)-3-aminopiperidin-1-yl]-3-methyl-2,4-dioxo-1,2,3,4tetrahydropyrimidin-1yl\}methyl)benzonitrile (C18H21N5O2), and its structure is shown in Figure 1 [8].

Analytical method validation ensures that various HPLC analytical techniques shall give reliable and repeatable results; it is a crucial step in developing new dosage forms as it provides information about accuracy, linearity, precision, detection, and quantitation limits. According to the ICH guideline, "the objective of validation of an analytical procedure is to demonstrate that it is suitable for its intended purpose." It is now obligatory in the process of drug development to supply the validation data for the responsible authorities. Guidelines for analysis method validation include ICH and USP guidelines [9-12].

Literature survey revealed a few methods reported for determination of alogliptin benzoate in bulk drug as well as pharmaceutical preparation $[2,5,13-16]$.

In this research, a new sensitive and rapid HPLC method was developed for the determination of alogliptin benzoate in pharmaceutical dosage forms, and this method was validated according to ICH and FDA guidelines.

\section{Materials and Methods}

2.1. Instrumentation. Agilent 1200 HPLC system was used for liquid chromatography method development and validation (Santa Clara, USA), equipped with a pump (model G1312A), an auto sampler (ALS) (model G1329A), and a Hypersil Gold Thermo Scientific C18 $(250 \mathrm{~cm} \times 4.6 \mathrm{~mm})$ $5 \mu \mathrm{m}$ column (Paisley, UK), and the detector consisted of UV/VIS operated at $277 \mathrm{~nm}$. Chemstation Software (Version Rev B.04.03 (16)) was used for data processing and evaluation.

2.2. Chemicals and Reagents. A pharmaceutical grade sample of alogliptin benzoate (assigned purity 99.4\%) was obtained as gift from Jordan Hikma Pharmaceuticals (Amman, Jordan). NESINA tablets containing $8.5 \mathrm{mg}$ alogliptin benzoate were purchased from the local market. Acetonitrile HPLC grade and ammonium carbonate were purchased from Merck (Merck Serono Amman, Jordan). The double distilled water was obtained from a local pharmaceutical company.

2.3. Chromatographic Conditions. The mobile phase was prepared by dissolving $1.0 \mathrm{gm}$ ammonium carbonate in $1000 \mathrm{ml}$ water. From the previous solution, $450 \mathrm{ml}$ was mixed with $550 \mathrm{ml}$ of acetonitrile. Prior to use the mobile phase was filtered through $0.45 \mu \mathrm{m}$ membrane filters and degassed by sonication for $10 \mathrm{~min}$. The analysis was carried out on an Agilent 1200 series HPLC system. The analytes were conducted on an analytical column C18, $5 \mu \mathrm{m}$,

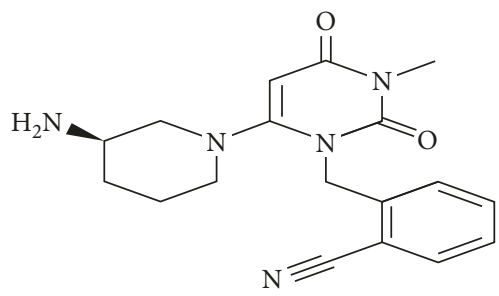

Figure 1: Chemical structure of alogliptin.

$250 \times 4.6 \mathrm{~mm}$ with a detection wavelength of $277 \mathrm{~nm}$. The operating temperature of the column was set at $30^{\circ} \mathrm{C}$. The injection volume was $10 \mu \mathrm{L}$, and the flow rate was maintained at $1.0 \mathrm{~mL} / \mathrm{min}$. The run time was 6 minutes.

2.4. Preparation of Standard Solution. A standard solution of alogliptin benzoate was prepared by dissolving an accurately weighed amount of alogliptin benzoate $(42.5 \mathrm{mg}$, which is equivalent to $31.25 \mathrm{mg}$ alogliptin) in $50 \mathrm{ml}$ of the mobile phase, and then $5 \mathrm{~mL}$ of the resulting solution was diluted to $25 \mathrm{~mL}$ by the same solvent to obtain a standard solution of alogliptin benzoate $(170 \mu \mathrm{g} / \mathrm{ml})$.

2.5. Preparation of Sample Solution. Twenty alogliptin tablets were weighed, triturated in porcelain mortar, and mixed, and the average weight of tablet was calculated. Accurately weighed amount of powder equivalent to $25 \mathrm{mg}$ of alogliptin (34 mg alogliptin benzoate) was transferred completely to a $200 \mathrm{~mL}$ volumetric flask, and $150 \mathrm{~mL}$ of the mobile phase was added and sonicated for 30 minutes. The volume was completed to mark by the same solvent to obtain a solution of alogliptin benzoate with a concentration of $170 \mu \mathrm{g} / \mathrm{ml}$. The prepared solution was filtered through $0.45 \mu \mathrm{m}$ membrane filters.

2.6. Method Validation. The method was validated as per $\mathrm{ICH}$ and FDA guidelines, and the validation parameters included specificity, linearity, range, accuracy, precision, sensitivity (LOQ and LOD), and robustness $[9,17]$.

2.6.1. Specificity. Specificity is one of the significant features of HPLC, and it refers to the ability of the analytical method to discriminate between the analyte and the other components in the complex mixture [18]. Specificity of the method was evaluated by injecting $10 \mu \mathrm{l}$ solutions of standard, sample, blank, and placebo separately.

2.6.2. Linearity. To evaluate the linearity and range of the method, different standard solutions were prepared by diluting the standard stock solution with the mobile phase in deferent concentrations of alogliptin benzoate: $85,136,170$, 204,255 , and $306 \mu \mathrm{g} / \mathrm{ml}$, which cover $50 \%, 80 \%, 100 \%, 120 \%$, $150 \%$, and $180 \%$ of the target concentration, respectively. Three injections from each concentration were analysed under the same conditions. Linear regression analysis was 
used to evaluate the linearity of the calibration curve by using the least square linear regression method.

2.6.3. Sensitivity. Limit of detection (LOD)/limit of quantitation (LOQ) of alogliptin benzoate were determined by analysing different solutions of alogliptin benzoate and measuring the signal-to-noise ratio. The limit of detection (LOD) is the concentration that gives a signal-to-noise ratio of approximately $3: 1$, while the limit of quantification (LOQ) is the concentration that gives a signal-to-noise ratio of approximately $10: 1$ with \%RSD $(n=3)$ of less than $10 \%$.

2.6.4. Accuracy. The accuracy of the assay method was determined by recovery studies at three concentration levels $(50 \%, 100 \%$, and $150 \%)$, i.e., 85,170 , and $255 \mu \mathrm{g} / \mathrm{ml}$, and three samples from each concentration were injected. The percentage recovery of added alogliptin benzoate and RSD were calculated for each of the replicate samples.

2.6.5. Precision. The system precision and method precision (repeatability) of the proposed methods were determined by several measurements of standard solution and sample solution, respectively [19-22]. System precision was established by ten measurements of the standard solution at the $100 \%$ concentration levels on the same day. Method precision was established by six assay determinations of the sample solution at the $100 \%$ concentration levels on the same day [23]. The RSD of obtained results was calculated to evaluate repeatability results.

2.6.6. Robustness. Robustness of the method was verified by applying minor and deliberate changes in the experimental parameters, for example:

(i) Column temperature: $\pm 5^{\circ} \mathrm{C}$

(ii) Flow rate: $\pm 0.2 \mathrm{~mL} / \mathrm{min}$

(iii) Wavelength: $\pm 3 \mathrm{~nm}$

(iv) Mobile phase composition, organic composition $\pm 5 \%$

Change was made to evaluate its effect on the method. Obtained data for each case was evaluated by calculating \% RSD and percent of recovery.

2.6.7. Stability of Analytical Solutions. The stability of analytical solutions was determined by analysing the standard and sample preparations at $0 \mathrm{~h}$ and after one day in refrigerator and at ambient room temperature $30^{\circ} \mathrm{C}$. Three injections from each solution were analysed, and the average of the peak and the RSD were calculated.

\section{Results and Discussion}

3.1. Method Development and Optimization. Several physical and chemical properties of alogliptin benzoate were obtained from the literature. The analytical method was developed to select preliminary reversed phase HPLC-UV chromatographic conditions, including detection wavelength, mobile phase, stationary phase, and sample preparation procedure. For this purpose, a series of trials were performed by varying the ratio of acetonitrile and ammonium carbonate buffer and optimizing the chromatographic conditions on the Hypersil Gold Thermo Scientific C18 $(250 \mathrm{~cm} \times 4.6 \mathrm{~mm}) 5 \mu \mathrm{m}$ column. The results of method optimization are summarized in Table 1.

The mobile phase consisting of acetonitrile and ammonium carbonate buffer in the ratio $55: 45 \mathrm{v} / \mathrm{v}$ with a flow rate of $1 \mathrm{~mL} / \mathrm{min}$, injection volume $10 \mu \mathrm{l}$, run time $6 \mathrm{~min}$, and column temperature $30^{\circ} \mathrm{C}$ at wavelength $(\lambda) 277$ was optimized as the best chromatographic conditions for the entire study where alogliptin benzoate was eluted forming symmetrical peak shape, resolution and suitable analysis time with retention time about $4 \mathrm{~min}$ (Figure 2).

\subsection{Method Validation}

3.2.1. Specificity. Specificity was evaluated by comparing the chromatograms of mobile phase blank, placebo solution, standard solution, and sample solution (alogliptin $170 \mu \mathrm{g} / \mathrm{ml}$ ). For this purpose, $10 \mu \mathrm{l}$ from solutions mobile phase blank, standard solution, and sample solution were injected into the HPLC system separately, and the chromatogram results are shown in Figures 2-5. It can be observed that there no coeluting peaks at the retention time of alogliptin benzoate interference. This result indicates that the peak of the analyte was pure and this confirmed the specificity of the method.

3.2.2. Linearity and Range. Analytical method linearity is defined as the ability of the method to obtain test results that are directly proportional to the analyte concentration, within a specific range. The mean peak area obtained from the HPLC was plotted against corresponding concentrations to obtain the calibration graph. The results of linearity study (Figure 6) gave linear relationship over the concentration range of $85-306 \mu \mathrm{g} / \mathrm{ml}$ for alogliptin benzoate. From the regression analysis, a linear equation was obtained: $y=17412 x+1.1377$, and the goodness-of-fit $\left(r^{2}\right)$ was found to be 1.00 , indicating a linear relationship between the concentration of analyte and area under the peak.

3.2.3. Limit of Detection and Limit of Quantification (LOD and LOQ). The limit of detection (LOD) is the lowest amount of analyte in a sample that can be detected, but not necessarily quantitated, while the limit of quantification (LOQ) is the lowest amount of analyte in a sample that can be quantitatively determined with suitable precision [24]. The results showed an LOD and LOQ for alogliptin of 0.03 and $0.09 \mu \mathrm{g}$, respectively.

3.2.4. Accuracy. The accuracy of an analytical procedure expresses the closeness of results obtained by that method to the true value. The results of accuracy showed percentage recovery at all three levels in the range of $99.4-101.9 \%$, and \% 
TABLE 1: Results of method optimization.

\begin{tabular}{|c|c|c|c|c|c|}
\hline Column used & Mobile phase & Flow rate & Wavelength & Observation & Result \\
\hline Restek C18, $125 \times 4.0 \mathrm{~mm}$ i.d., $5 \mu \mathrm{m}$ & $\begin{array}{c}\text { (Buffer: methanol) } \\
(45: 55) \mathrm{v} / \mathrm{v}\end{array}$ & $1.0 \mathrm{ml} / \mathrm{min}$ & $216 \mathrm{~nm}$ & Poor resolution 1.4 & Method rejected \\
\hline $\begin{array}{l}\text { Thermo Scientific C18, } \\
250 \times 4.6 \mathrm{~mm} \text { i.d., } 5 \mu \mathrm{m}\end{array}$ & $\begin{array}{c}\text { (Buffer : acetonitrile) } \\
(25: 75) \mathrm{v} / \mathrm{v}\end{array}$ & $1.0 \mathrm{ml} / \mathrm{min}$ & $277 \mathrm{~nm}$ & Poor resolution 1.6 & Method rejected \\
\hline $\begin{array}{l}\text { Thermo Scientific C18, } \\
250 \times 4.6 \mathrm{~mm} \text { i.d., } 5 \mu \mathrm{m}\end{array}$ & $\begin{array}{c}\text { (Buffer : acetonitrile) } \\
(45: 55) \mathrm{v} / \mathrm{v}\end{array}$ & $1.0 \mathrm{ml} / \mathrm{min}$ & $277 \mathrm{~nm}$ & Good resolution 2.4 & Method accepted \\
\hline
\end{tabular}

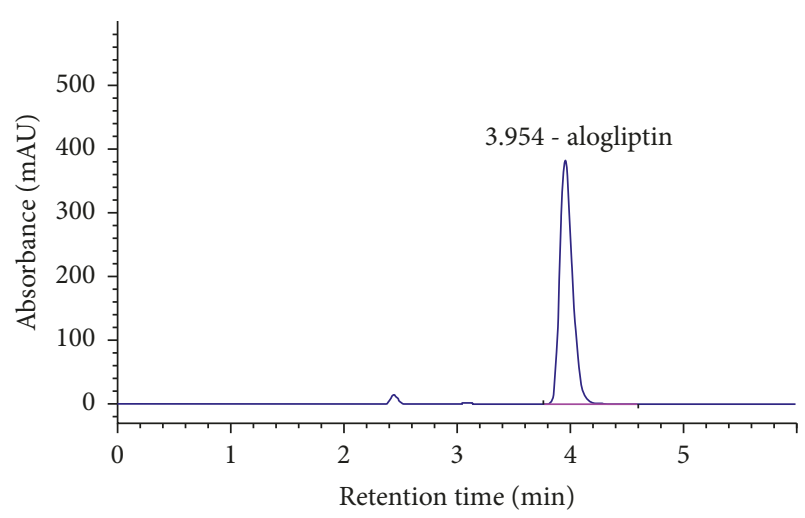

FIgURE 2: Chromatogram of alogliptin standard solution.

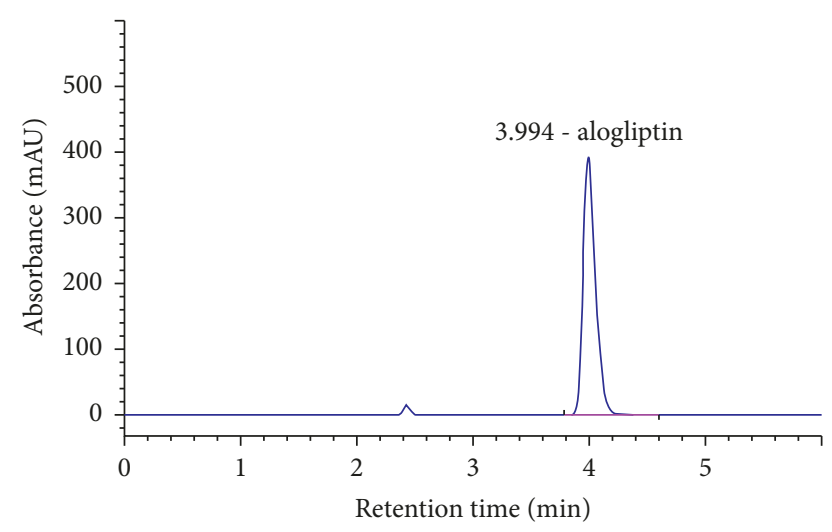

Figure 3: Chromatogram of alogliptin sample solution.

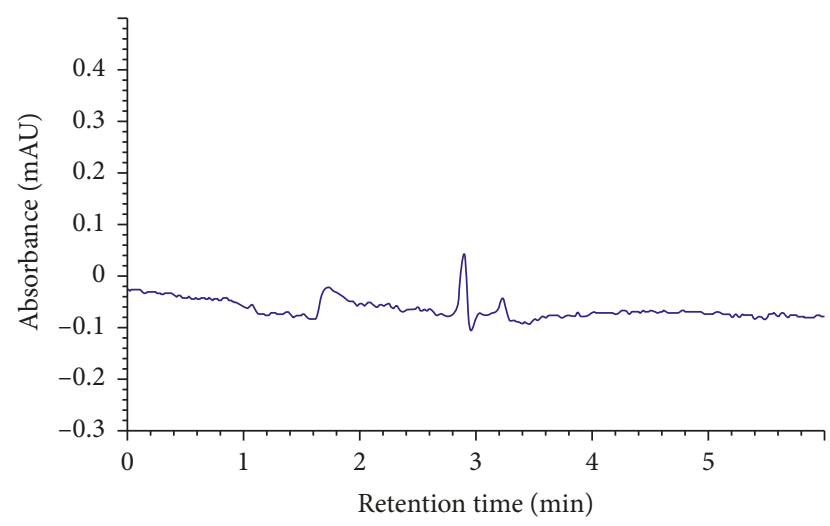

Figure 4: Chromatogram of blank solution.

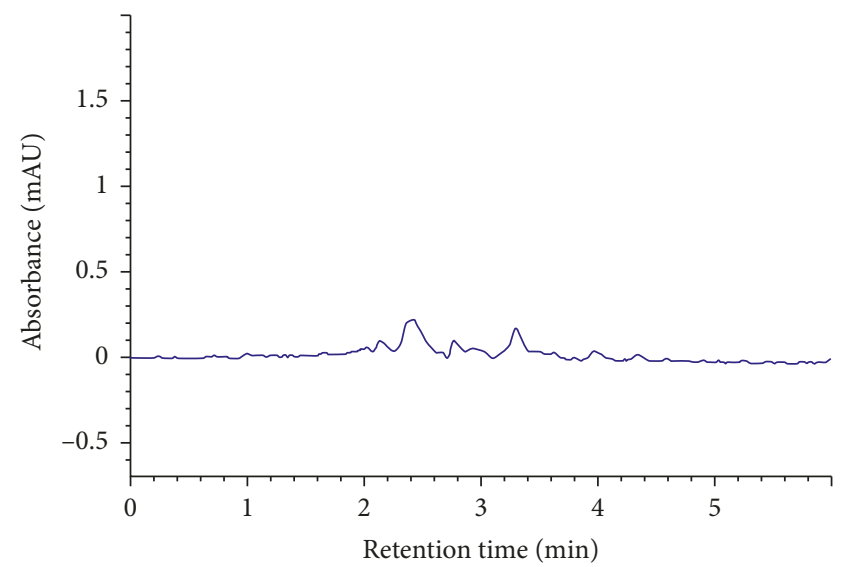

FIGURE 5: Chromatogram of placebo solution.

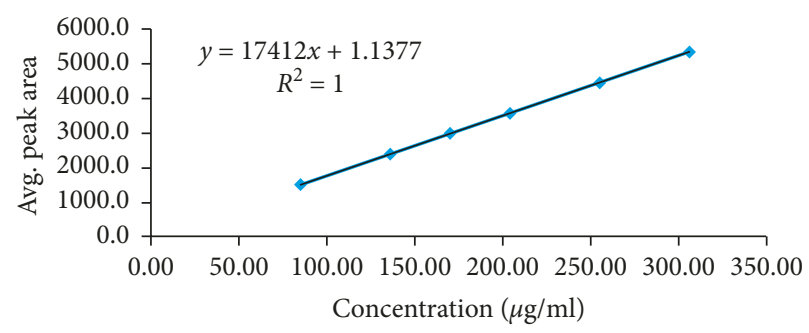

FIGURE 6: Standard calibration curve of alogliptin benzoate.

RDS values were in the range of $0.06-0.43 \%$ as shown in Table 2 . The results of percentage recovery and \%RSD were within the accepted limits from $98.0 \%$ to $102.0 \%$ and not more than $2.0 \%$, respectively, which indicates the applicability of the method for routine drug analysis.

3.2.5. Precision. The precision of the method is defined as "the closeness of agreement between a series of measurements obtained from multiple sampling of the same homogeneous sample under the prescribed conditions," and it is normally expressed as the relative standard deviation [25].

The results of both system and method precision showed that the method is precise within the acceptable limits. The $\mathrm{RSD}$, tailing factor, and number of theoretical plats were calculated for both solutions; all the results are within limits. Acceptable precision was not more than $2.0 \%$ for the RSD and the tailing factor and not less than 1000 for number of plates, as shown in Tables 3 and 4 . 
TABLE 2: Recovery data of the proposed HPLC method.

\begin{tabular}{|c|c|c|c|c|}
\hline$\%$ spiked level & Replicate number & Peak area & $\%$ recovery & Mean \%RSD \\
\hline \multirow{3}{*}{50} & 1 & 1508.4 & 101.9 & 101.5 \\
\hline & 2 & 1495.5 & 101.0 & \multirow{2}{*}{0.43} \\
\hline & 3 & 1503.5 & 101.6 & \\
\hline \multirow{3}{*}{100} & 1 & 2950.7 & 99.4 & 99.4 \\
\hline & 2 & 2950.8 & 99.4 & \multirow{2}{*}{0.06} \\
\hline & 3 & 2953.8 & 99.5 & \\
\hline \multirow{3}{*}{150} & 1 & 4443.5 & 100.2 & 100.1 \\
\hline & 2 & 4435.4 & 100.0 & \multirow{2}{*}{0.13} \\
\hline & 3 & 4431.9 & 99.9 & \\
\hline Mean (\% of recovery) & $98.0-102.0$ & & 100.318 & \\
\hline$\% \mathrm{RSD}$ & Max 2.00 & & 0.964149 & \\
\hline
\end{tabular}

TABLE 3: System precision data from the standard solution of the proposed HPLC method.

\begin{tabular}{lcccc}
\hline Replicate number & RT & Peak area & Number of theoretical plates & Tailing factor \\
\hline 1 & 3.954 & 2952 & 1.32 & 6274 \\
2 & 3.956 & 2951 & 1.36 & 6388 \\
3 & 3.961 & 2951 & 1.35 & 6363 \\
4 & 3.959 & 2960 & 1.33 & 6364 \\
5 & 3.961 & 2953 & 1.36 & 6386 \\
6 & 3.965 & 2946 & 1.36 & 6441 \\
7 & 3.962 & 2949 & 1.38 & 6479 \\
8 & 3.965 & 2950 & 1.35 & 6486 \\
9 & 3.965 & 2954 & 1.35 & 6464 \\
10 & 3.969 & 2958 & 1.33 & 6471 \\
\hline Average & 3.962 & 2952 & 1.3 & 6412 \\
\%RSD & - & 0.10 & - & - \\
\hline
\end{tabular}

TABLE 4: Method precision data from the sample solution of the proposed HPLC method.

\begin{tabular}{|c|c|c|c|c|c|}
\hline \multicolumn{6}{|c|}{ Alogliptin $6.25 \mathrm{mg}$ tablet } \\
\hline Replicate number & $\mathrm{RT}$ & Peak area & Tailing & Plates & $\%$ assay \\
\hline 1 & 4.025 & 3009 & 1.54 & 8086 & 99.2 \\
\hline 2 & 4.024 & 3012 & 1.52 & 8049 & 99.2 \\
\hline 3 & 4.027 & 3009 & 1.48 & 8101 & 99.2 \\
\hline 4 & 4.027 & 3009 & 1.49 & 8105 & 98.6 \\
\hline 5 & 4.028 & 3015 & 1.50 & 8039 & 99.3 \\
\hline 6 & 4.027 & 3012 & 1.50 & 8107 & 99.5 \\
\hline Average & 4.026 & 3011.0 & 1.5 & 8081 & 99.2 \\
\hline$\%$ RSD & - & 0.1 & & & 0.31 \\
\hline
\end{tabular}

3.2.6. Robustness. The analytical method robustness was tested by evaluating the influence of minor modifications in HPLC conditions on system suitability parameters of the proposed method, as mentioned in Section 2.6.6. The results of robustness testing showed that a minor change of method conditions, such as the composition of the mobile phase, temperature, flow rate, and wavelength, is robust within the acceptable limits. The results are summarized in Table 5. In all modifications, good separation of alogliptin benzoate was achieved, and it was observed that the percent of recovery was within acceptable limits and the \%RSD is within limit of not more than $2.0 \%$. The tailing factors and number of theoretical plates were found within acceptable limits as well.

3.2.7. Solution Stability. The percent of recovery was within the range of $98.0 \%$ to $102.0 \%$ and RSD was not more than $2.0 \%$, indicating a good stability of the sample and standard solutions for $24 \mathrm{hr}$ at both conditions. The percent of recovery was within acceptable limits, and the \%RSD is within the limit of not more than $2.0 \%$. The tailing factors and number of theoretical plates were found within acceptable limits as well. The results are shown in Table 6. 
TABLE 5: Robustness data of the proposed HPLC method.

\begin{tabular}{lccc}
\hline Parameter & & \%RSD of standard peak area & \%RSD of assay \\
\hline \multirow{2}{*}{ Column temperature } & $25^{\circ} \mathrm{C}$ & 0.07 & 0.15 \\
& $30^{\circ} \mathrm{C}($ normal) & 0.03 & 0.19 \\
Wavelength & $35^{\circ} \mathrm{C}$ & 0.04 & 0.2 \\
& $274 \mathrm{~nm}$ & 0.06 & 0.07 \\
& $277 \mathrm{~nm}$ (normal) & 0.03 & 0.19 \\
Mobile phase composition & $280 \mathrm{~nm}$ & 0.06 & 0.17 \\
& $-5 \%$ acetonitrile & 0.05 & 0.20 \\
Flow rate & Normal & 0.03 & 0.19 \\
& $+5 \%$ acetonitrile & 0.02 & 0.14 \\
\hline
\end{tabular}

TABLE 6: Solutions stability data of the proposed HPLC method.

\begin{tabular}{|c|c|c|c|c|c|c|c|}
\hline Parameter & & RT & $\begin{array}{l}\text { Avg. peak } \\
\text { area }\end{array}$ & $\begin{array}{l}\text { RSD peak } \\
\text { area }(\%)\end{array}$ & Tailing factor & Recovered (\%) & $\begin{array}{l}\text { Number of } \\
\text { theoretical plates }\end{array}$ \\
\hline \multirow{3}{*}{ Standard solution } & $0 \mathrm{~h}$ & 4.034 & 3022.7 & 0.07 & 1.5 & - & 8058 \\
\hline & After $24 \mathrm{~h}$ at $30^{\circ} \mathrm{C}$ & 4.035 & 3021.7 & 0.2 & 1.6 & 100.0 & 8143 \\
\hline & After $24 \mathrm{~h}$ at refrigerator & 4.049 & 2983.7 & 0.08 & 1.5 & 98.7 & 8137 \\
\hline \multirow{3}{*}{ Sample solution } & $0 \mathrm{~h}$ & 4.034 & 2995.7 & 0.07 & 1.5 & - & 8142 \\
\hline & After $24 \mathrm{~h}$ at $30^{\circ} \mathrm{C}$ & 4.035 & 3001.3 & 0.3 & 1.5 & 100.2 & 8179 \\
\hline & After $24 \mathrm{~h}$ at refrigerator & 4.036 & 3000.0 & 0.2 & 1.6 & 100.1 & 8188 \\
\hline
\end{tabular}

\section{Conclusion}

In the present research, a fast, simple, accurate, precise, and linear stability-indicating HPLC method has been developed and validated for alogliptin benzoate, and hence it can be employed for routine quality control analysis. The analytical method conditions and the mobile phase solvents provided good resolution for alogliptin benzoate. In addition, the main features of the developed method are short run time and retention time around $4 \mathrm{~min}$. The method was validated in accordance with ICH guidelines. The method is robust enough to reproduce accurate and precise results under different chromatographic conditions.

\section{Data Availability}

The data used to support the findings of this study are available from Dr. Hani shtaya (hshtaya@birzeit.edu) upon request.

\section{Conflicts of Interest}

The authors declare no conflicts of interest in publication of this research.

\section{Acknowledgments}

This research was supported by Hikma Pharmaceutical Company (Jordan).

\section{References}

[1] A. B. Olokoba, O. A. Obateru, and L. B. Olokoba, "Type 2 diabetes mellitus: a review of current trends," Oman Medical Journal, vol. 27, no. 4, pp. 269-273, 2012.

[2] K. Zhang, P. Ma, W. Jing, and X. Zhang, "A developed HPLC method for the determination of alogliptin benzoate and its potential impurities in bulk drug and tablets," Asian Journal of Pharmaceutical Sciences, vol. 10, no. 2, pp. 152-158, 2015.

[3] C. Chen, C. M. Cohrs, J. Stertmann, R. Bozsak, and S. Speier, "Human beta cell mass and function in diabetes: recent advances in knowledge and technologies to understand disease pathogenesis," Molecular Metabolism, vol. 6, no. 9, pp. 943957, 2017.

[4] M. Rendell, A. Drincic, and R. Andukuri, "Alogliptin benzoate for the treatment of type 2 diabetes," Expert Opinion on Pharmacotherapy, vol. 13, no. 4, pp. 553-563, 2012.

[5] K. Sharma and A. Parle, "Development and validation of HPTLC method for estimation of alogliptin benzoate in bulk drugs and tablet dosage forms," International Bulletin of Drug Research, vol. 5, no. 8, pp. 81-89, 2015.

[6] W. Kim and J. M. Egan, "The role of incretins in glucose homeostasis and diabetes treatment," Pharmacological Reviews, vol. 60, no. 4, pp. 470-512, 2008.

[7] K. Y. Kavitha, G. Geetha, R. Hariprasad, M. Kaviarasu, and R. Venkatnarayanan, "Development and validation of stability indicating RP-HPLC method for the simultaneous estimation of linagliptin and metformin in pure and pharmaceutical dosage form," Journal of Chemical and Pharmaceutical Research, vol. 5, no. 1, pp. 230-235, 2013. 
[8] P. Supriya, N. L. Madhavi, K. Rohith, G. Ramana, U. Harini, and A. Pawar, "Development and validation of UV spectrophotometric and reversed Phase-high performance liquid chromatography-PDA methods for the estimation of alogliptin benzoate," Asian Journal of Pharmaceutical and Clinical Research, vol. 9, no. 1, pp. 282-287, 2016.

[9] ICH Guideline, "Validation of analytical procedures: text and methodology," in Proceedings of International Conference on Harmonization, Topic Q2 (R1), Geneva, Switzerland, November 2005.

[10] S. Chandran and R. S. P. Singh, "Comparison of various international guidelines for analytical method validation," Pharmazie, vol. 62, no. 1, pp. 4-14, 2007.

[11] T. M. Kalyankar, P. D. Kulkarni, S. J. Wadher, and S. S. Pekamwar, "Applications of micellar liquid chromatography in bioanalysis: a review," Journal of Applied Pharmaceutical Science, vol. 4, no. 1, pp. 128-134, 2014.

[12] R. N. El-Shaheny, M. H. El-Maghrabey, and F. F. Belal, "Micellar liquid chromatography from green analysis perspective," Open Chemistry, vol. 13, no. 1, pp. 877-892, 2015.

[13] M. M. Mabrouk, S. F. Hammad, F. R. Mansour, and M. M. Amer, "Development and validation of a reversed phase HPLC method for simultaneous determination of antidiabetic drugs alogliptin benzoate and pioglitazone $\mathrm{HCl}$," Der Pharmacia Sinica, vol. 7, no. 2, pp. 32-40, 2016.

[14] K. S. Potdar, M. S. Kalshetti, and R. Y. Patil, "Development and validation of a novel RP-HPLC method for simultaneous estimation of alogliptin benzoate and pioglitazone HCL in pharmaceutical dosage form," International Journal of Chemical and Pharmaceutical Analysis, vol. 4, no. 3, 2017.

[15] P. B. Deshpande and S. R. Butle, "Stability indicating high performance thin layer chromatographic determination of alogliptin benzoate as bulk drug and in tablet dosage form," Eurasian Journal of Analytical Chemistry, vol. 12, no. 4, pp. 325-335, 2017.

[16] N. T. Lamie and M. A. Mahrouse, "Smart spectrophotometric methods based on normalized spectra for simultaneous determination of alogliptin and metformin in their combined tablets," Spectrochimica Acta Part A: Molecular and Biomolecular Spectroscopy, vol. 204, pp. 743-747, 2018.

[17] FDA, CDER, Beers, and Donald, Analytical Procedures and Methods Validation for Drugs and Biologics Guidance for Industry, FDA, Silver Spring, MD, USA, 2015.

[18] N. Batrawi, H. Naseef, and F. Al-Rimawi, "Development and validation of a stability-indicating HPLC method for the simultaneous determination of florfenicol and flunixin meglumine combination in an injectable solution," Journal of Analytical Methods in Chemistry, vol. 2017, Article ID 1529280, 7 pages, 2017.

[19] C. M. Riley, T. W. Rosanske, and S. R. R. Riley, Specification of Drug Substances and Products: Development and Validation of Analytical Methods, Elsevier, New York, NY, USA, 2014.

[20] A. Agarwal, S. Tiwari, and K. Nagariya, "Method development and its validation for quantitative simultaneous determination of latanoprost, timolol and benzalkonium chloride in ophthalmic solution by RP-HPLC," Journal of Drug Delivery and Therapeutics, vol. 3, no. 2, 2013.

[21] N. R. Poola, D. Bhuiyan, S. Ortiz et al., "A novel HPLC assay for pentamidine: comparative effects of creatinine and inulin on GFR estimation and pentamidine renal excretion in the isolated perfused rat kidney," Journal of Pharmacy and Pharmaceutical Sciences, vol. 5, no. 2, pp. 135-145, 2002.
[22] S. Chandran, R. S. P. Singh, and A. Sajeev Chandran, "Comparison of various international guidelines for analytical method validation,” Pharmazie, vol. 62, pp. 4-14, 2007.

[23] M. Veeramachaneni and K. R. Jayavarapu, "Development and validation of new ICP-OES analytical technique to quantify the contents of copper, magnesium and zinc in 'escitalopram oxalate," Journal of Pharmacy and Pharmaceutical Sciences, vol. 3, no. 4, pp. 516-523, 2013.

[24] A. Forootan, R. Sjöback, J. Björkman, B. Sjögreen, L. Linz, and M. Kubista, "Methods to determine limit of detection and limit of quantification in quantitative real-time PCR (qPCR)," Biomolecular Detection and Quantification, vol. 3, pp. 1-6, 2017.

[25] FDA-Guidance for Industry, Validation of Analytical Procedures: Definition and Terminology Final Guidance, FDA, Silver Spring, MD, USA, 2010. 

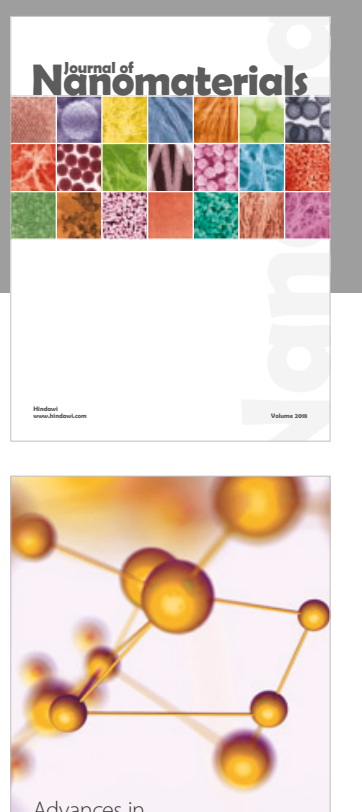

Physical Chemistry
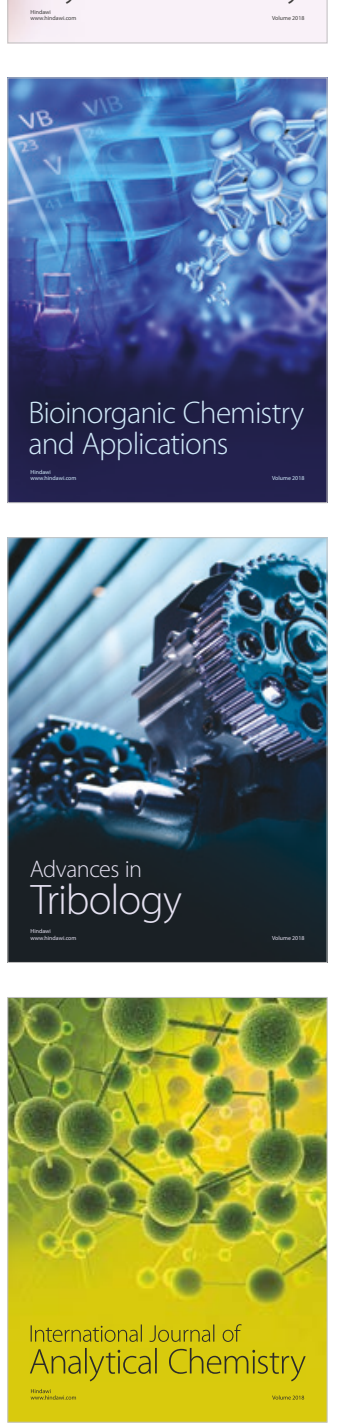

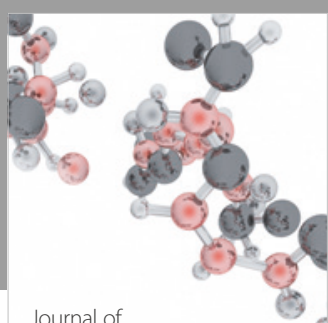

Analytical Methods

in Chemistry

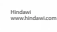

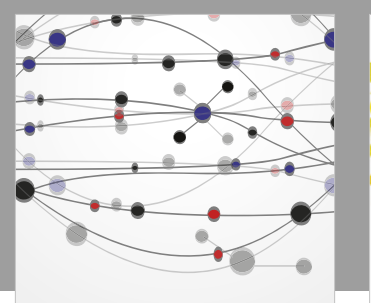

The Scientific World Journal

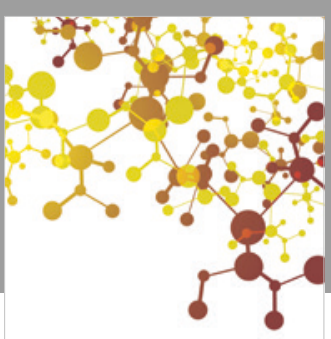

Journal of

Applied Chemistry
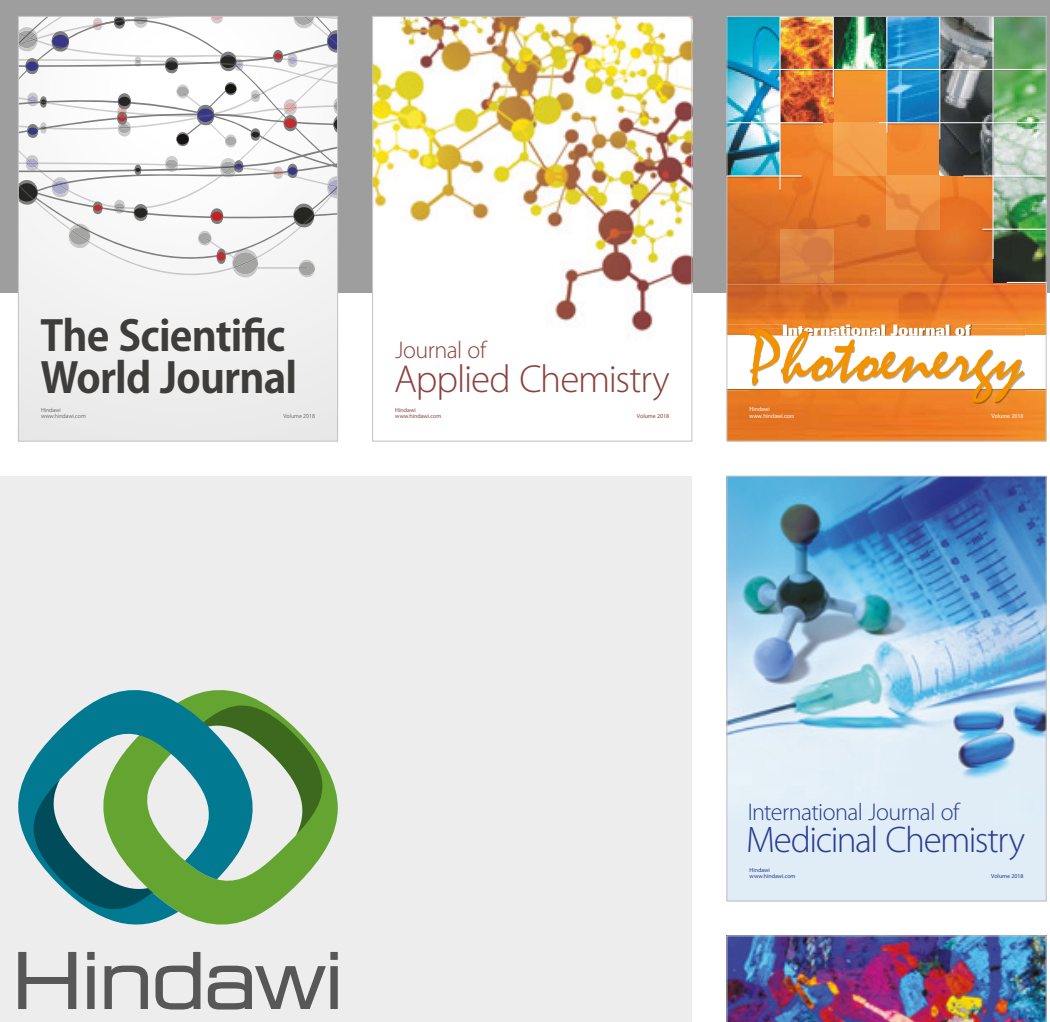

Submit your manuscripts at

www.hindawi.com
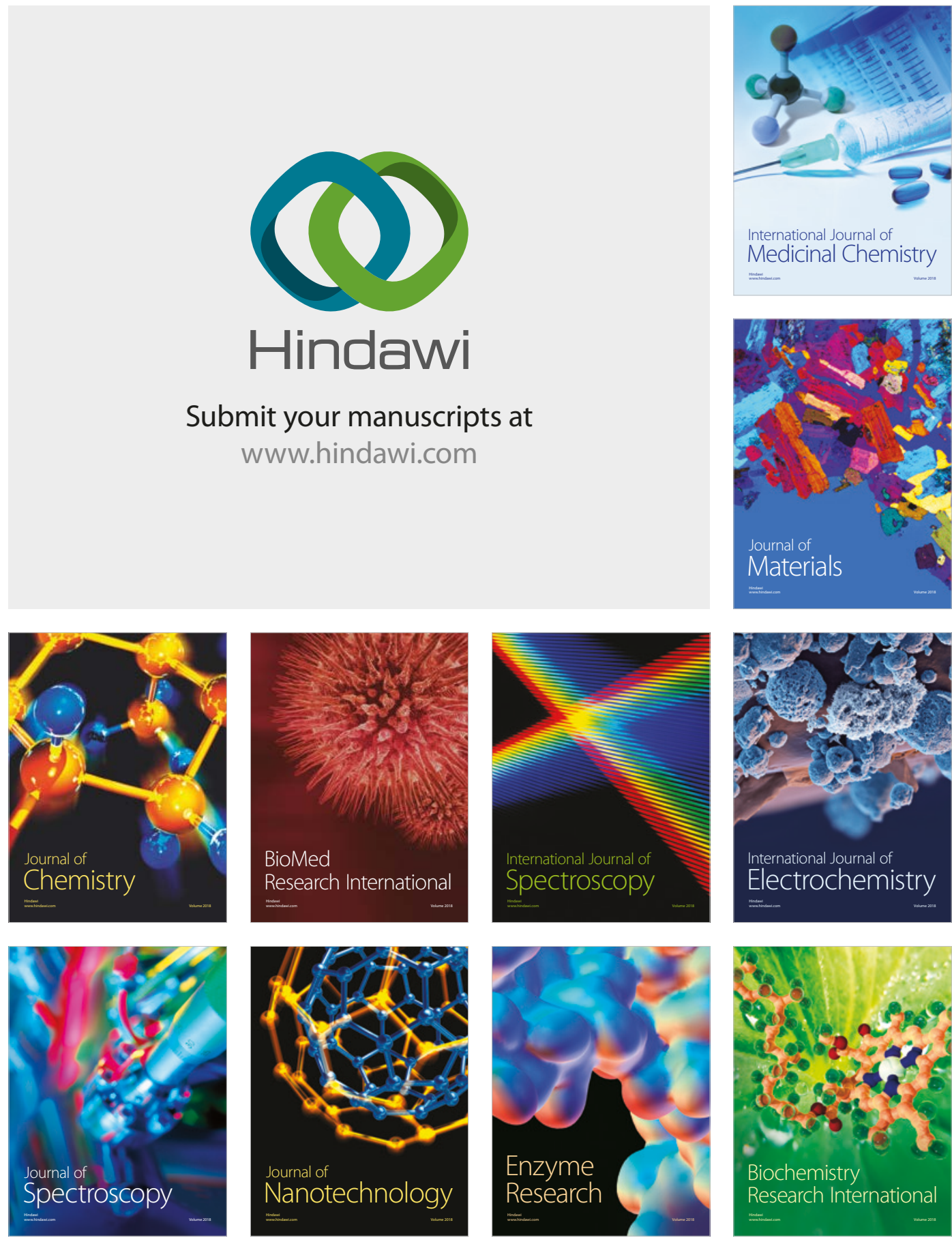
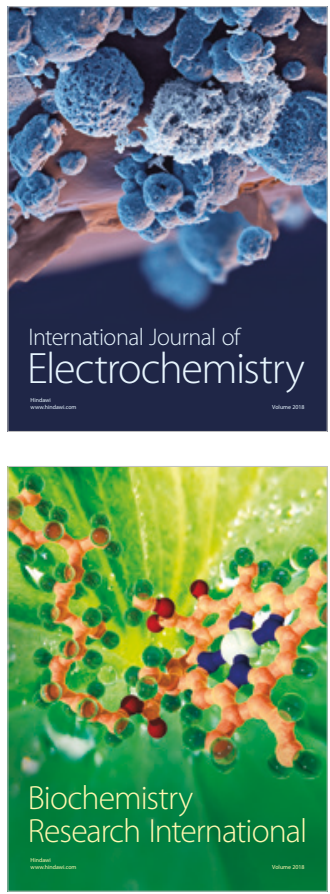